\title{
The essence, features and prospects of homestead land use in Uzbekistan
}

\author{
Abdullo Ashurov ${ }^{1, *}$ and Guzal Saydaliyeva ${ }^{1}$ \\ ${ }^{1}$ Tashkent Institute of Irrigation and Agricultural Mechanization Engineers (TIIAME), State \\ Cadastres Department, 39 Kari Niyazov Street, Uzbekistan
}

\begin{abstract}
The socio-economic role of homestead land plots and private farms is studied, definitions of their terms are given, the role of the homestead land Fund in ensuring food security of the country and increasing the export potential of fruit and vegetable products is considered. The reasons for the higher efficiency of growing agricultural products in private farms in comparison with other forms of farming, as well as the features of the use of homestead land plots, are studied.

Keywords. Land Fund, types of land, resource, Land plots, household, subsidiary farm, dehkan farm, property, inheritance, service life, efficiency, use, rent, massive
\end{abstract}

\section{Introduction}

The article emphasizes the importance of rural settlements, in particular, the role of the land Fund of households in the national economy. Indicators of agricultural production, animal husbandry and their low profitability, food shortage and ways to solve these problems are given. Managers of dehkan farms in different regions analysed the results of surveys, the costs of agricultural production and organization of production, as well as the average volume of production on land plots. Prospects for continuous development of land use in farms. In addition, the prospects of using GIS in the management of land use and farms are highlighted. One of the key factors for sustainable land use is the efficient management of natural resources. Dehkan farms should be developed on a systematic basis, including the creation of normal living conditions for the population, provision of agricultural products to rural families through the introduction of resource-saving technologies and optimization of the use of private land, reasonable year-round crop rotation, export of surplus industrial products, and restoration of soil fertility.

\section{Situation Analysis}

The area of homestead lands of the Republic is 697.3 thousand. Ha, including 453.7 thousand acreages. Ha, of which 422.9 thousand. Ha of irrigated land, which is a significant part of the irrigated acreage from their total area in the Republic - 12.96. \% [1]. homestead land is intended for housing and farm buildings of citizens living in rural areas, as well as

* Corresponding author: a.ashurov2810@gmail.com 
for gardening in order to meet the needs of the family in crop production and animal husbandry based on the use of personal labour of family members. Surplus products can be sold on the market at the discretion of the family.

At present, there are 4,596,415 million rural families in the Republic with homesteads and homesteads (LPH). Homestead plots of land are granted to the head of the family on the basis of an inherited lifetime right, their size varies in the irrigated area of agriculture from 0.06 to 0.25 hectares, in the rain-fed zone from 0.25 to 0.25 hectares, in the desert. zone - from 0.50 to 1.0 ha [2]. Despite the relatively small share of irrigated land in the household Fund, their contribution to ensuring the country's food security is quite large: as of January 1, 2001 the share of dehkan (personal subsidiary) farms in all categories of cattle farms was 86.2 percent, as of January 1, 2017, 94.1 percent. In the analysed period, there was also an increase in this proportion in the following species: cows - from 89.9 to 94.5 percent, sheep and goats - from 67.4 to 83.8 percent, pigs - from 44.3 percent to 78.7 percent, horses - from 70.2 percent to 85.0 percent, camels - from 33.1 percent to 62.4 percent, bee colonies - from 50.0 percent to 74.1 percent. The share of dehkan (private subsidiary) farms in all categories of farms in meat production in 2000 and 2016 was 91.1 and 94.4 percent, respectively, milk-93.7 and 95.6 percent, eggs-59.9 and 57.3 percent, wool-74.3 and 85.4 percent. Karakul skins - 32.1 and 83.7 percent, honey-55.3 and 79.2 percent. [3].

Every year, the share of these farms in the export of agricultural products increases. However, practice shows that the production potential of the land of the economic Fund in a market economy is not fully used. Not all homesteads are re-sown (re-sown); only a small portion of homesteads receive three crops a year (mainly in the Surkhandarya region). There is no qualitative assessment of these lands; when calculating the amount of land tax from household plots, the average score of the soil bonus of the administrative district is used, which to a certain extent distorts the amount of payments [4]. Private land that plays a significant role in the socio-economic development of the Republic is not classified as an independent category, the nature and features of its use are not studied, and there are no programs for the development of this land Fund. they are not developed or implemented at the state or local level, and the effectiveness of their use is not monitored. For various reasons, a significant part of the land of the household Fund is used inefficiently; with rational use, much larger volumes of agricultural products can be obtained from these lands. In this regard, the President of the Republic of Uzbekistan and the Cabinet of Ministers of the Republic of Uzbekistan have taken appropriate measures to improve the efficiency of land use in the country $[5,6,7,8,9$, etc. $]$.

The use of the land plots of the Foundation were studied by many Russian scientists (e.g., $[10,11,12,13.14$, etc.] and foreign $(15.16,17$, etc.). However, currently there is no single clear concepts and definitions of the terms "personal land", "private farming" rural families, and there is no clear difference in terms of "private farms" and "private farm. The land code of the Republic of Uzbekistan also does not define " private land "and" private land for own farming. In view of the above, we consider the nature and features of the use of land of the economic Fund in General and private land, especially.

\section{Methodology}

Homestead plots are plots of residential buildings (estates) of rural families. They are issued for life the head of the rural family to build a house, outbuildings, and farming based on family labour to meet the needs of the family necessary products. The terms "household plot" and "personal subsidiary farm", which are typical mainly for the CIS countries, including Uzbekistan, were introduced in the former Union in the standard Charter of an agricultural cooperative, adopted in 1930 under conditions of complete collectivization. 
The new Model Regulation on agricultural cooperatives, discussed and adopted by the second all-Union Congress of collective farmers, confirms the transfer of personal plots to the families of collective farmers. At the same time," Personal subsidiary farming of collective farm yards on household plots seems to be an objective necessity" [18].

The reason for the appearance of the terms "homestead land" and "personal subsidiary farms" is that in the former Soviet Union, all land was nationalized, in agriculture it was transferred to collective farms - collective farms and state farms for the production of commercial agricultural products. In this regard, in the conditions of continuing collectivization of agriculture and insufficient state economic support for the rural population to meet the personal socio-economic needs of the rural family, the need to maintain a small personal subsidiary farm to meet the needs of the family. was recognized. Without a household, the rural population would not be able to live normally due to the lack of natural and monetary income from social production, especially during the economic crisis. On the lands of a specially created personal Fund, a new organizational and economic form of personal family economy ( $\mathrm{LFH}$ ) was created, from which each family was provided with homestead plots.

In the unified land Fund of the former Soviet Union and in the Land funds of the former Union republics, including the Republic of Uzbekistan for state registration of land plots of the land Fund included a graph "private land" introduced the reflection area of private farms, household plots of land. Currently, in the Republic of Uzbekistan, this column has been preserved in the Land Fund, which reflects the quantitative indicator of the homestead land Fund of rural areas. The official language it is called "Tomarka yer uchastkasi".

Thus, a household land plot (ROM) is a land plot attached to a house (estate) intended for personal subsidiary farming based on the use of personal labour of family members. Private farming (LPH) rural family economic use of plots of land based on family labour to ensure the provision of housing, essential food crops and livestock. Moreover, if the surplus of agricultural products increases, the family has the right to sell them on the market at its discretion. However, it cannot be interpreted as a commodity economy. Consequently, the personal subsidiary economy of a rural family is based on the use of household land and the labour of the family itself; this is not a commodity economy. In scientific sources, the term "personal subsidiary farms" is used to refer to the activities of households in the field of crop production and animal husbandry. "Household" is a form of economic activity that covers economic objects and processes that occur in the places of permanent residence of a person and family [19].

The concept of "private farm" is formulated in the Law of the Republic of Uzbekistan "On dehkan farms" [14], which, unlike private farming is treated as a small-scale farm, because along with providing a family of agricultural dehkan farm produces marketable products. Activities in the dehkan economy are considered to be entrepreneurial activities and can be carried out at the request of members of the dehkan economy with or without a legal entity. "A dehkan farm is a small family farm engaged in the production and sale of agricultural products based on the personal labour of family members on an infield plot of land and on additional plots outside the community, granted to the head of the family for life by inheritance" [14]. Activities in the dehkan economy are considered to be entrepreneurial activities and can be carried out at the request of members of the dehkan economy with or without a legal entity. A dehkan farm cannot use wage labour on a permanent basis in its activities. Members of a dekhkan household are the head of the family, his spouse, children, including foster children, foster children, parents, and other relatives who have reached working age, live together and have a dekhkan household. At the same time, it should be taken into account that the dehkan economy is based on the use of a private land plot. 
The lands of the Republican Economic Fund have a deep socio-economic essence, and it should be noted that the value of these lands is constantly increasing. The social significance of land increases with increasing demands for increased investment in human potential. Economic importance is growing in the context of the development of a market and innovative economy, which requires a significant increase in the efficiency of agricultural land use, especially irrigated land. The area of household plots in rural settlements has increased by 341.7 thousand over the past 28 years (from 1990 to 2018). as of January 1, 2019-697.3 ha. the number of farms reached 4.596 million. The size of homesteads ranges from 0.08 to 0.35 ha in irrigated agricultural land, up to 0.5 ha on land, and up to 1.0 ha in the desert. The average size of LPH is $0.15 \mathrm{ha}$, and in the irrigation zone 0.12 ha. They are granted on the right of hereditary possession to the head of the family [2]. It should be borne in mind that the dehkan economy, which is a small-scale economy and high-commodity farms, simultaneously also use the homestead land plots provided for their family needs.

At the same time, land plots provided for individual housing construction (IHS) cannot be considered homestead plots, since they are not aimed at providing the family with the necessary agricultural products. In connection with the above, it should be recognized that the concept of a personal land plot (LPH) and a personal subsidiary farm of a rural family (LPH) applies exclusively to the CIS countries, including the Republic of Uzbekistan.

Currently, the land of the economic Fund is located in several categories of land of the Unified State Fund (EGF), mainly in the category of agricultural land. This indicates that homestead lands do not have a status in the DHF structure and are not systematized within a single category of land. We believe that the land of personal homesteads in the strict sense of the word is the land of rural settlements and should be considered in the category of land of localities, they do not have a target agricultural commodity function. homestead plots and homestead plots based on them for rural families have played and continue to play an important role in social support and material support for rural families since they were granted official status. Their importance is especially growing in the context of the development of market relations in land use and innovation economy. A significant role in this regard is assigned to the lands of the economic Fund in the Concept of land and water resources use in agriculture [17] and in the Draft Strategy for the development of agriculture of the Republic of Uzbekistan for 2020-2030. [18]. the Functioning of personal lands has the following features in their use:

- the concept of a household plot (ROM) and a personal subsidiary farm of a rural family (LPH), their existence and functioning is typical only for the CIS countries, including the Republic of Uzbekistan, since their concept and terms originated in the former Soviet Union;

- homestead plots are granted on the right of inherited ownership only to families permanently residing in rural areas, and they are granted not only to families engaged in agricultural production, but also to citizens of other professions permanently working in this rural area. (teachers, doctors, locksmiths, electricians, etc.);

- in the Republic of Uzbekistan in the absence of a land market and HOMESTEAD land cannot be sold on the land market, the sale of a residential house on the plot right to lifetime inherited possession of a land plot shall be transferred to the new owner of the house;

- personal owner of land may transfer land to a family member or a close relative, right of disposition of land - sale, barter, donation - he has no;

- homestead plots are allocated within the boundaries of rural settlements in accordance with their master plan for development or reconstruction, since there is no system of farm settlements in the Republic;

- for many rural families, income from household plots is either the only source or a priority, which dictates the need for efficient use of land; 
- land plots of the Republic's forest Fund make up a significant percentage of the total area of irrigated land, which requires a comprehensive increase in land use efficiency in market conditions and water scarcity;

- in the conditions of Uzbekistan the utilization of agricultural land on private land is higher than the state cultivated land, and approximately equal $\mathrm{K}=2$; at the same time in the southern regions of the country it may be increased to $\mathrm{K}=3$;

- in the areas of irrigated agriculture of the Republic, private land plots must be provided with irrigation water for their full use, which is stipulated by the Land code of the Republic of Uzbekistan;

- since homestead plots are provided to all families permanently residing in rural areas, the heads of farms and dehkan farms, in addition to commodity production sites, have land plots on which they also maintain a personal subsidiary farm;

- the quality of land (productivity) of HOMESTEAD plots in rural settlements is usually higher than the quality of public land. Owners of small homesteads pay much more attention to the reproduction of soil fertility: the introduction of organic fertilizers in a much larger amount per unit area, timely prevention of salinization and waterlogging of the land, prevent soil erosion, as a rule, qualitatively and timely carry out pre-sowing tillage, significantly more invest in high-quality manual labor to care for crops.

The development of a market economy requires the rational use of all types of resources and, above all, land. The land of rural settlements and especially the land stock of households play an important role in the country's land use. Its effective use contributes to increasing the production of agricultural and livestock products in the country, the development of small businesses and private entrepreneurship, improving the supply of food to the population, increasing employment and increasing incomes of the rural population. "The rural worker is a strong pillar of life, a pillar of our well-being," President of the Republic of Uzbekistan Shavkat Mirziyoyev said at a solemn meeting dedicated to the day of the agricultural worker on December 9, 2017. in his speech: "in the field of agriculture, there are still untapped opportunities that are waiting for their solution to problems and shortcomings." In his speech, "445 thousand hectares of the most fertile land were transferred to the population in private plots". But the use of these sites is small." [6]. The use of one of these opportunities, indicated in the speech of the President of the Republic, is largely determined by a comprehensive increase in the efficiency of land use by dehkan farms. Despite significant progress in the development of dehkan farms, in the land use of rural settlements and, above all, dehkan farms, there are still problems: improvement of land reclamation, issues of providing feed, pasture areas, etc. the provision of land in the sublease [12]. Real vesting of the right of lifelong hereditary ownership of a private land plot with a pledge obligation, mortgage registration, improvement of roads and transport communications, processing of grown products, implementation of scientifically based crop rotation on a private land plot, etc. All this requires a solution and further improvement of the legal framework for land use in rural settlements.

An analysis of the state and use of existing land in rural settlements indicates insufficient efficiency of its use, including the land of dehkan farms. Free land use, which for many years determined the inappropriate use of land in our country, contributed to the inefficient, irrational use of this valuable resource, which led to the hypertrophied growth of the territories of settlements and the unjustified withdrawal of agricultural land for construction. into extremes. The length of engineering and transport communications has increased, the environment around localities has degraded, and the cost of all types of development of their territories has increased [8]. All this had a negative impact on the efficiency of the use of personal land and the quality of the population. The main reasons for this situation were the lack of reliable accounting of rural settlements ' land, the 
necessary urban planning documentation for their integrated development, and the deterioration of land reclamation in rural areas [11].

\section{Materials and Methods}

During the agrarian and land reform, a new organizational and legal management structure was formed in the village - a small family dehkan farm that produces and sells surplus agricultural products (based on the personal labor of family members on the provided private land plot). As a lifelong legacy of mine ownership) [14]. The dynamics of production shows that the share of this type of farms in the total gross agricultural output is constantly increasing and amounts to $81 \%$ of potatoes, $56 \%$ of melons, $66 \%$ of vegetables, $50 \%$ of grapes; almost all the country's livestock is concentrated here -6.5 million heads (92.8\%), including 2.8 million cows (94.5\%); they account for 95\% - meat, 97\% - milk, $57.9 \%$ - eggs, $71.7 \%$ - wool produced in the country [13].

At the same time, an analysis of the current state and use of private land in the Republic shows that their potential is far from exhausted. On the homestead plots, they receive mostly no more than 2 crops, due to which the dehkans meet their needs for potatoes and vegetables, and sell the surplus on the market. Crops such as early (winter) cabbage, beets, and some others are still rarely used. Livestock indicators are quite low; the lack of feed is due to a small area of land. Food crops are mainly grown in the garden. High-quality land plots are low. Mineral fertilizers are often not applied in sufficient quantities, irrigation is not always carried out in the best agrotechnical terms and with the required rate, the land of villages is often located on massive saline lands, and the collector and drainage network within the village is not removed in a timely manner. There is no optimization of the structure of crops and their economically feasible alternation in the garden.

Surveys of dehkan farms in different regions of the country showed that the cost of doing business is $1000-2000$ thousand soums. (excluding animal husbandry costs) the cost of production is $4000-6000$ thousand soums, income is $2000-4000$ thousand soums. or an average of about 3000 thousand soums per family. More than $85 \%$ of dehkan farms contain livestock and poultry. About $70 \%$ of households keep cash cows, including $35 \%$ of fattened calves. The productivity of cows on farms is quite low - about $1700 \mathrm{~kg}$ of milk. On average, about $1,100 \mathrm{~kg}$ of milk and $150 \mathrm{~kg}$ of meat are consumed per family annually, which is 3.3 and 5.25 million rubles. soums, respectively. The cost of agricultural products sold from animal husbandry is an average of 3.7 million rubles. Sum, and in General, taking into account crop production, 4.9-5.0 million. Sums. The average consumption of farmed products by a family is $60-65 \%$ (approximately 3.2 million people). Soums), the rest of the products are sold on the market. The experience of advanced dehkan farms and research shows that their efficiency can be increased three to four times.

Decree of the First President of the country I. A. Karimov No. PP-308 dated 23.03.2006 in order to further develop dehkan farms, strengthen their role in agricultural production and provide state assistance to the rural population, persons engaged in cattle breeding in private subsidiary farms have the right to create employment records and register work. experience. In addition, it provides for the allocation of cash cows to low-income families through sponsorship. The number of livestock is increasing, but providing them with feed remains a problem. The provision of animals with their own feed is insufficient $(25-30 \%$ due to corn, barley meat and vegetable stalks) [1]. Pastures and pasture feed are particularly lacking. Currently, almost all agricultural land in the Republic is distributed among farms, and not every farmer allows representatives of dehkan farms to graze cattle even on the outskirts of their plots or collect hay on the farm. Summer and winter pastures are located very far from populated areas. 


\section{Results and Discussion}

One of the key factors for sustainable land use is the efficient management of natural resources. Dehkan farms should develop on a systematic basis, including creating normal conditions for the population's life, providing rural families with agricultural products through the introduction of resource-saving technologies and optimizing the use of the territory of the household land plot, reasonable year-round crop rotation, export of surplus industrial products, and restoration of soil fertility. The following aspects of long-term development of land use of dehkan farms can be distinguished:

1. Rational organization of the territory of dehkan farms; This aspect provides for rational placement of residential and economic premises, perennial plantings and crops (vegetable garden) and land on the territory of a personal land plot. The most suitable form is rectangular, which provides the most effective layout of the territory for construction, placement of a garden and vegetable garden. The layout of the plot of land should provide maximum comfort for family living, household management and recreation, necessary sanitary and hygienic conditions and fire safety, rational use of land and water in harmony with the improvement of the village.

2. Allocation of additional territories from the number of irrationally used and unused lands (including pastures); Not all dehkan farms have the corresponding areas specified in the Land code of the Republic. If we analyze dehkan farms that are successfully functioning and have good indicators, their areas can be expanded to normal. It is necessary to develop a mechanism for allocating pasture territory. The expansion of the land use area of a dehkan farm should take into account the resources available to the family (financial and labor), which guarantee the effective use of land.

3. Rational distribution of crops and land; it provides for the selection and placement on personal plots of such types and varieties of crops that provide the necessary optimal alternation all year round. At the same time, the constant alternation of crops should not Deplete the land, but rather restore and increase soil fertility. Provide for the restoration of soil fertility on the basis of a rational farming system, the introduction of soil protection technologies and the preservation of humus. The land, when used correctly, restores its productive properties. The development of society, the continuous growth of its population and needs objectively require an expanded nature of agricultural production, which is the reason for the need for expanded reproduction of soil fertility [10].

4. The use of geographic information systems (GIS);

The problem of managing the land resources of rural settlements and, above all, the personal land Fund has always been relevant. The increase in the number of economic entities on earth as a result of increase in population plots of the land Fund has begun expanding the circle of participants in land relations. Modern works on territorial planning, land management, cadastre and environmental assessment necessarily involve the use of geographical information systems (GIS), which will make fundamental changes in the field of information support for management decisions [7].

As the object of research, we selected the lands of subsidiary farms and dehkan farms in Surkhandarya region, which are an ideal testing ground for developing an information and management system to support the system using GIS based on land inventory for making operational management decisions. To create a system of land management of households and dekhkan farms using GIS technologies, we used the method of system analysis of land use rationality and allocation of land plots of irrational land use, illegal use, methods of land observation: yard, inventory geodetic surveys of areas, methods of data organization by creating a geodata database, methods of spatial and logical modeling. The automated cartographic system (EX), which is the core of GIS for land management of households and 
dehkan farms, has been developed and tested for a fragment of land in homesteads and dehkan farms and is a set of software tools that ensure the creation and direct use of maps.

It is advisable to create a complete GIS for managing the territories of subsidiary and dehkan farms in 2 stages: preparatory and production. The preparatory stage includes: collection, analysis and systematization of archival land cadastre data, planning and cartographic materials, land management documentation for land plots (allotment materials, land inventory materials, land books), as well as data on the composition and population. To Refine and update the planning and cartographic material, as well as to speed up and reduce the cost of work, you can use remote sensing data that is refined at the production stage during geodetic surveys. In addition to surveys and bypass the yard, at the production stage are carried out surveying and cadastral works, in which the application and correction (adjustment) of boundaries, boundaries, parcels, areas of farms and dehkan farms, boundaries of individual land mass and land.

In addition to surveys and bypass the yard, at the production stage are carried out surveying and cadastral works, in which the application and correction (adjustment) of boundaries, boundaries, parcels, areas of farms and dehkan farms, boundaries of individual land mass and land. As a result, digital maps of the area are created and a GEODATA database (EGDB) is created.

Land plots are formed according to topological rules, which allows you to exclude incorrect data, such as overlapping land plots or, conversely, a gap between them.

The geodata database is a spatial-logical model that can be used for:

- inventory of land of subsidiary and dehkan farms;

- monitoring the state of engineering communication networks;

- support, updating and development of the General plan of a rural settlement, construction of detailed planning projects;

- information support for selecting a location for the construction of warehouses, warehouses of commercial objects (for example, purchasing organizations) that require a detailed spatial analysis of the territory;

- information services and consultations for potential users of land and real estate: spatial information about the reference and market value of land plots, cartographic services of real estate databases.

\section{Conclusion}

A large amount of accumulated information and integration of geographic information systems (GIS) allows you to quickly and fully meet a wide variety of information needs both in content and in form - in the form of reports, thematic maps, analytical results in electronic and paper form for information support of management decision-making. Testing the results of a study conducted on the example of homestead and dehkan farms in Surkhandarya region showed that GIS is an effective tool for managing land resources in rural settlements, for example:

- in the field of Economics-determining the current state of land use, identifying opportunities to optimize and improve the use of land in private and dehkan farms in the region by changing the territorial and sectoral structure of land, analyzing its state and development trends.

- in the field of ecology-identifying the features of the ecological state of land and preventing the development of negative processes.

Reliable and complete information about land resources helps to increase budget revenues from land payments, organize its rational use and protection, promptly regulate land relations and introduce a regulated land market. 
We thank the staff of the Department of land resources and state cadastre of Sherabad, Denav, Sariosiyo and Uzun districts of Surkhandarya region (Uzbekistan) and the scientific supervisor of this study, doctor of Economics, Professor A. S. Chertovitsky.

\section{References}

1. A. F. Ashurov, Economic potential of land use in rural settlements "AGRO ILM" Scientific Appendix to the journal "Agriculture of Uzbekistan", Volume-1, P. 89-90 (2009)

2. Yu. S. Balandin, Peasant economy. Moscow, Agropromizdat (1992)

3. A.V. Chayanov, Peasant economy. Selected works. Moscow "Economy" (1989)

4. Decree of the President of the Republic of Uzbekistan "On measures for the effective use of land and water resources in agriculture" dated June 17, No. up-5742 (2019)

5. G. Kudratov, E. Akramov, Reform of agriculture in the Republic of Uzbekistan Personal subsidiary farms. Agricultural journal of Uzbekistan, No. 3, P. 2-3 (2001)

6. Sh. M. Mirziyoyev, "Speech at the solemn meeting on the occasion of the day of agricultural workers on December 9 (2017)

7. A. L. Paul, F. G. Michael, J. M. David, V. R. David, Geographical information systems and science. Great Britain, 2nd edition "Zhohn wili and sons, Ltd.", p.517 (2005)

8. V. P. Proshlyakov, Inter-Farm land management in conditions of irrigated agriculture P. 94-95 (1964)

9. Resolution of the Cabinet of Ministers of the Republic of Uzbekistan "On additional measures to support homeowners and develop scientific and practical potential in the field of agriculture of the Ferghana region " dated October 10, No. 846 (2018)

10. G. A. Talipov, Monograph "Land resources of Uzbekistan and problems of their rational use", Tashkent (1992)

11. P. K. Tatur, Monograph "Settlement System and principles of settlement planning for agricultural enterprises", Volume-3, p.29 (1975)

12. Concept of land and water resources use in agriculture. Decree of the President of the Republic of Uzbekistan dated June 17 (2019)

13. Land code of the Republic of Uzbekistan, approved by the Law of the Republic of Uzbekistan of April 30, 1998 N 598-I; Entered into force on July 1, 1998. The resolution of the Oliy Majlis of 30 April 1998 No. 599-IR, as amended by Law of RU of August 30, 2003 N 535-II, Law of the Republic of Uzbekistan dated 30.04. 2004 No. 621-II of the law of the Republic of Uzbekistan dated 03.12.2004 No. 714-II, Law of the Republic of Uz from 28.12.2004 G. 2007 N LRU-138 (1998)

14. The law of the Republic of Uzbekistan "On dehkan farms", Tashkent, with changes and additions (1998)

15. A. Uralov, D. Nozilov, A. Farmonov, S. Matyazov, Agricultural Planning, Tashkent "Uzbekistan" P.65-75 (1994)

16. E. E. Rumyantseva, New economic encyclopedia. M.: Infra-M. p.541 (2011)

17. The Concept of using land and water resources in agriculture. Appendix No. 1 to the Decree of the President of the Republic of Uzbekistan dated June 17, "up-5742" (2019)

18. Strategy for the development of agriculture of the Republic of Uzbekistan for 20202030. Project, Tashkent, Ministry of agriculture of the Republic of Uzbekistan, (2019) 
19. I. V. Bochkov, P. N. Pershin, M. A. Snegirev, V. F. Sharapov-History of land relations and land management, State publishing house of agricultural literature, Moscow, P.162-163. Literature, Moscow. 